\title{
Ellipsis
}

Volume 44

Article 18

2017

\section{Sponge Paint Makes Me Think of Cold Cups}

Jasmine K. Holloway

University of New Orleans

Follow this and additional works at: https://scholarworks.uno.edu/ellipsis

\section{Recommended Citation}

Holloway, Jasmine K. (2017) "Sponge Paint Makes Me Think of Cold Cups," Ellipsis: Vol. 44 , Article 18. DOI: https://doi.org/10.46428/ejail.44.18

Available at: https://scholarworks.uno.edu/ellipsis/vol44/iss1/18

This Poetry is brought to you for free and open access by the Department of English and Foreign Languages at ScholarWorks@UNO. It has been accepted for inclusion in Ellipsis by an authorized editor of ScholarWorks@UNO. For more information, please contact scholarworks@uno.edu. 


\section{Sponge Paint Makes Me Think of Cold Cups}

Jasmine Holloway

blue kool aid

in a big bowl

stirred with a soup kitchen spoon

until the blue taste like

more sugar

dripped into a $20 \mathrm{oz}$ ounce

tossed in the ice box from school evening

to school morning.

Palms sweaty

digging in my navies

for lunch money change.

"Three dollars my babies."

Across the street she always watched me

run inside my house

for a crippled dollar

in daddy's day old work pants.

Her screen door opened again for us to accept my sticky bright blue plastics and my not-so-exact change.

After licking blue sugar

my bright blue tongue on brown skin

says

not to be natural. 